$9-2007$

\title{
Multiaxial Thermo-Mechanical Fatigue on Material Systems for Gas Turbines
}

\author{
M. Bartsch \\ Institut für Werkstoff-Forschung \\ B. Baufeld \\ Katholieke Universiteit \\ M. Henzelmann \\ Fachhochschule Bonn-Rhein-Sieg
}

Anette M. Karlsson

Cleveland State University, a.karlsson@csuohio.edu

S. Dalkilic

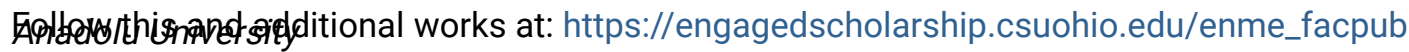

Part of the Mechanical Engineering Commons

Seew doxt pagefess additiohal wouthors

Publisher's Statement

This is the accepted version of the following article: Bartsch, M., Baufeld, B., Heinzelmann, M., 2007, "Multiaxial Thermo-Mechanical Fatigue on Material Systems for Gas Turbines," Materialwissenschaft Und Werkstofftechnik, 38(9) pp. 712-719., which has been published in final form at http://onlinelibrary.wiley.com/doi/10.1002/mawe.200700193/abstract

\section{Original Citation}

Bartsch, M., Baufeld, B., Heinzelmann, M., 2007, "Multiaxial Thermo-Mechanical Fatigue on Material Systems for Gas Turbines," Materialwissenschaft Und Werkstofftechnik, 38(9) pp. 712-719.

This Article is brought to you for free and open access by the Mechanical Engineering Department at EngagedScholarship@CSU. It has been accepted for inclusion in Mechanical Engineering Faculty Publications by an authorized administrator of EngagedScholarship@CSU. For more information, please contact library.es@csuohio.edu. 


\section{Authors}

M. Bartsch, B. Baufeld, M. Henzelmann, Anette M. Karlsson, S. Dalkilic, and L. Chernova 


\title{
Multiaxial thermo-mechanical fatigue on material systems for gas turbines
}

\author{
Mehrachsige thermomechanische Ermüdung an Werkstoffsystemen \\ für Gasturbinen
}

M. Bartsch ${ }^{1}$, B. Baufeld ${ }^{2}$, M. Heinzelmann ${ }^{3}$, A. M. Karlsson ${ }^{4}$, S. Dalkilic ${ }^{5}$, L. Chernova ${ }^{1}$

\author{
Dedicated to Prof. Wolfgang Bunk on the occasion of his $80^{\text {th }}$ birthday
}

\begin{abstract}
Material systems made from nickel based superalloys with protective coatings have been tested in thermo-mechanical fatigue with superposed thermal gradients, which generated multiaxial stress states. The testing conditions were selected for simulating the fatigue loading in the wall of an internally cooled gas turbine blade of an aircraft engine. After thermo-mechanical testing the damage behaviour of the materials has been investigated by means of microscopic methods. The laboratory experiments have been accompanied by numerical simulations. Based on the results of the simulations and observed damage features the test parameters in subsequent laboratory tests have been controlled to facilitate the validation of models describing the initiation and propagation of damages. This contribution gives an overview over results on the influence of multiaxial stress states on (i) oriented deformation and coagulation of $\gamma$ '-precipitates ('rafting') in the substrate, (ii) on morphological instabilities of the surface of metallic oxidation protection coatings ('rumpling'), and (iii) on crack initiation and growth in material systems with additional ceramic thermal barrier coating.

Keywords: multiaxial stress state, thermo-mechanical fatigue,
\end{abstract} thermal gradient, thermal barrier coating, material modelling

\section{Introduction}

The stress state of cooled components in hot engines is multiaxial due to the thermal gradients over the component's wall, if thermal expansion is constrained. In a laboratory, it is difficult and for some cases impossible to simulate the real stress states without generating thermal gradients. In real components often additional mechanically induced stresses are superposed, which influence the stress state and the damage behaviour in the material as well. If the laboratory testing fails to simulate the service conditions adequately, non-realistic damage mechanisms may be achieved. As a consequence, the test results may be misleading with respect to the behaviour of the tested materials in service and do not allow lifetime

1 Institut für Werkstoff-Forschung, Deutsches Zentrum für Luftund Raumfahrt e.V., Köln

2 Katholieke Universiteit Leuven, Belgium

3 Fachhochschule Bonn-Rhein-Sieg, Rheinbach

4 University of Delaware, Newark, USA

5 Anadolu University, College of Civil Aviation, Eskisehir, Turkey
An Werkstoffsystemen aus beschichteten Nickel-Basis Superlegierungen wurden thermomechanische Versuche mit überlagerten Temperaturgradienten durchgeführt, die in den Proben mehrachsige Spannungszustände erzeugen. Die Versuchsbedingungen wurden so gewählt, dass sie möglichst realistisch die Ermüdungsbeanspruchungen in der Wand einer gekühlten Gasturbinenschaufel eines Flugzeugtriebwerks nachbilden. Im Anschluss an die Versuche wurden die Werkstoffe mikrostrukturell und mikroanalytisch hinsichtlich ihres Schädigungsverhaltens untersucht. Die Laborversuche wurden von numerischen Berechnungen begleitet. Auf Grundlage der numerischen Simulation und der beobachteten Schädigungsbilder wurden die Versuchsparameter so gesteuert, dass Hypothesen zur Schädigungsentstehung und -entwicklung überprüft werden konnten. Der Beitrag gibt einen Überblick über Ergebnisse zum Einfluss der Mehrachsigkeit der Beanspruchung (i) auf die gerichtete Deformation und Koagulation von $\gamma^{\prime}$-Ausscheidungen ('Floßbildung') im Substrat, (ii) auf die Oberflächenaufrauhung von metallischen Oxidationsschutzschichten ('Rumpling') und (iii) auf Rissbildung und -wachstum in Werkstoffsystemen mit zusätzlicher keramischer Wärmedämmschicht.

Schlüsselworte: Mehrachsigkeit, thermomechanische Ermüdung, Temperaturgradienten, Wärmedämmschicht, Werkstoffmodellierung assessments. In order to generate realistic damage and failure behaviour as observed in material systems for internally cooled components in gas turbines, a test facility was designed and built, which allows simultaneous to thermal mechanical fatigue loading the superposition of a high thermal gradient over the specimen wall. Material systems for gas turbine blades have been tested under different controlled stress states, which have been calculated by numerical simulations. After testing, the materials have been investigated by microscopic methods in order to identify the damage mechanisms. Utilizing the microstructural findings, the damage evolution has been simulated by adapting and developing material models and implementing them into finite element models. Furthermore, analytical and numerical analyses have been used to design experiments for validating hypotheses concerning the damage mechanisms in the material systems.

The main goal of the performed work is to understand and further quantify the influence of controlled high thermal gradients in thermomechanical cycling on the damage and failure behaviour of the material systems used in gas turbine blades. This contribution gives an overview over results from several years of research on the effect of multiaxial stress states due to thermal gradients. The paper focuses on (i) oriented deforma- 
tion and coagulation of $\gamma$ '-precipitates ('rafting') in the nickel based substrate, which influences the creep properties [1], on (ii) morphological instabilities of the surface of metallic oxidation protection coatings ('rumpling'), which can induce fatigue cracks starting at the surface [2], and on (iii) crack initiation and growth in material systems with additional ceramic thermal barrier coating, which impair the thermal insulation by the coating.

\section{Experimental}

\subsection{Specimens and test facility}

In all tests hollow, dog bone shaped, specimens were used with two different geometries - one type of test specimens had an inner diameter of $4 \mathrm{~mm}$ and an outer diameter of $8 \mathrm{~mm}$, the other specimen type had an inner diameter of $7.5 \mathrm{~mm}$ and an outer diameter of $10 \mathrm{~mm}$. The metallic oxidation protection coating was about $100 \mu \mathrm{m}$ thick and, if applied, the ceramic thermal barrier coating (TBC) was about $200 \mu \mathrm{m}$ thick. The specimens were subjected to thermal mechanical cyclic loading with different multiaxial stress states. The mechanical load was applied by a servo-hydraulic testing machine and the thermal load with a radiation furnace powered by quartz lamps. The outer surface temperature of the specimen was controlled with a thin wire thermocouple ( $\varnothing 0.3 \mathrm{~mm}$, Type $S$ ) enlacing the specimen. The maximum temperature set-point value was in the range of $950{ }^{\circ} \mathrm{C}$ to $1100^{\circ} \mathrm{C}$, depending on the specific investigation. The minimum set-point value was about $100^{\circ} \mathrm{C}$. High cooling rates were achieved with an active air cooling from vents in a shutter, which was introduced into the furnace by a pneumatic device and enclosed the specimen during the cooling cycle. The temperature of the external cooling air was about $20^{\circ} \mathrm{C}$. By removing the shutter under full radiation power, very high heating rates were attained. During the thermal gradient fatigue testing the specimen was permanently internally cooled by a constant air flow in the range of 45 to 100 norm liters per minute, depending on the specimen type and selected stress state. Internal cooling and external heating

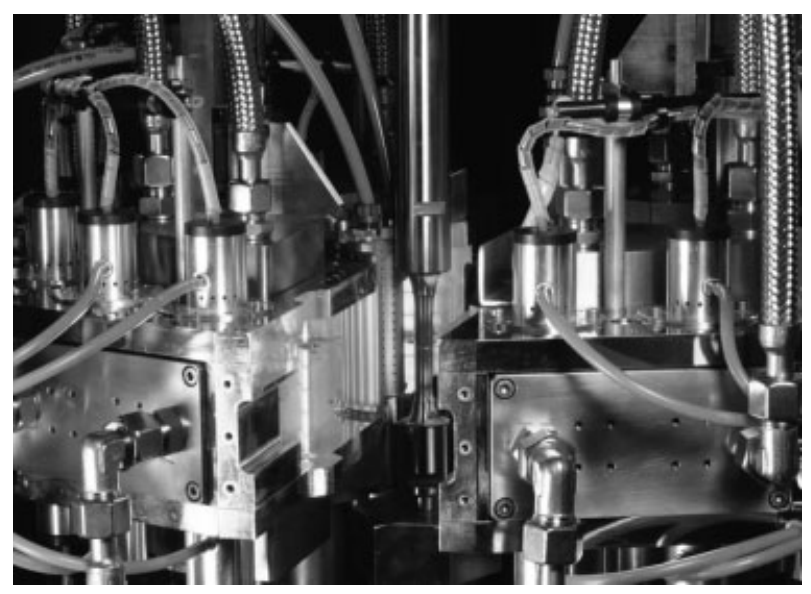

Figure 1. View of the open radiation furnace with the specimen in the centre and one half of the shutter with vents for external cooling introduced into the furnace.

Bild 1. Geöffneter Strahlungsofen der TGMF-Anlage mit der Probe im Zentrum und einer Hälfte des Schiebers mit Ventilen für die externe Kühlung der Probenoberfläche im Ofenraum and cooling, respectively, generated time dependent thermal gradients over the cross section of the specimen. The temperature difference between the outer and the inner surface was measured by means of a calibration specimen with sheet thermocouples. A view of the open radiation furnace with one half of the shutter introduced into the furnace is shown in figure 1.

Because of the thermal gradient, the test was called thermal gradient mechanical fatigue (TGMF), in contrast to thermomechanical fatigue (TMF). By imposing the thermal gradient in laboratory testing, each layer of the coated specimen is tested at the realistic temperature, which is not possible in conventional TMF with homogenous temperature distribution over the specimen wall. Furthermore, the thermal gradient in a laboratory test induces a multi-axial stress field similar to that in an internally cooled turbine blade. In the cylindrical specimen, mainly biaxial stresses are obtained. These are compressive at the outer surface and tensile at the inner surface for the axial and circumferential direction, see figure 2 .

The TGMF tests are performed under load control with tensile mechanical loads, which represent the centrifugal forces in a rotating gas turbine blade. Figure 3 shows the outer surface temperature and the mechanical nominal load related to the substrate cross section during the course of one exemplary TGMF test cycle. The duration of one TGMF cycle was about $2 \mathrm{~min}$ up to $3 \mathrm{~min}$ and aimed to simulate the entire low cycle fatigue load of a turbine blade during one flight.

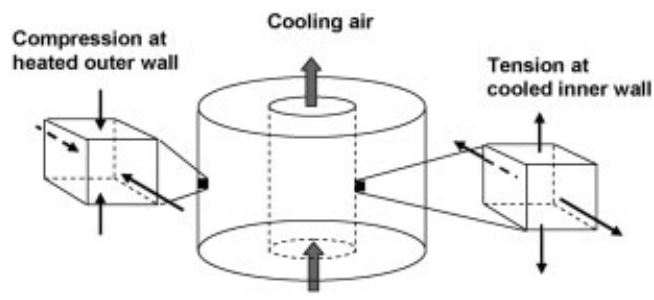

Figure 2. Illustration of the stress state in a tubular specimen due to external heating and internal cooling

Bild 2. Schematische Darstellung des Spannungszustands in einer rohrförmigen Probe infolge einer äußeren Heizung und gleichzeitiger Innenkühlung

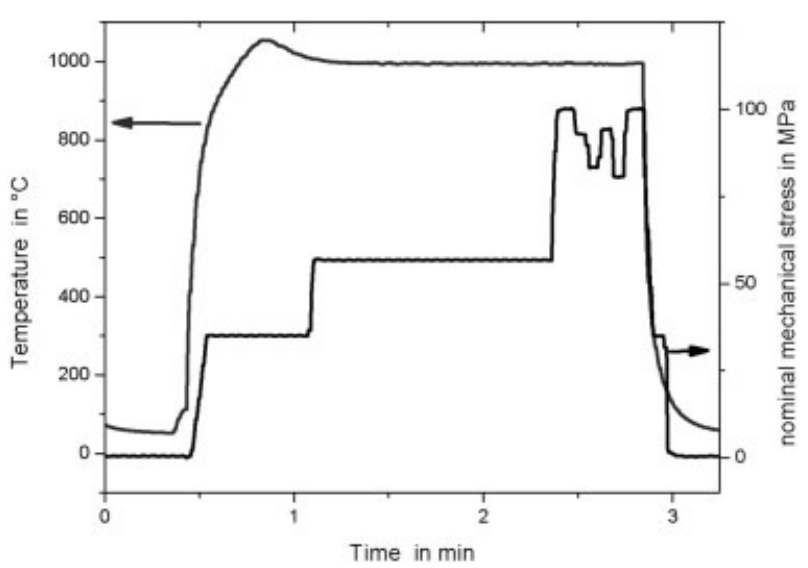

Figure 3. Typical thermal mechanical load cycle in TGMF testing, showing the course of the temperature at the outer surface and the nominal mechanical stress

Bild 3. Typischer thermomechanischer Lastzyklus in einem TGMF-Test mit dem Temperaturverlauf an der äußeren Probenoberfläche und der nominalen mechanischen Spannung 


\subsection{Material systems}

The tests specimens are made from two nickel based superalloys with different coating systems. For the specimens with an outer diameter of $10 \mathrm{~mm}$, single crystalline CMSX- $4{ }^{\circledR}$ was used as substrate material. The [100] direction of the single crystal was nominally in length axis of the specimens, which is the axis of the mechanically applied load. CMSX $-4^{\circledR}$ is a second-generation single-crystalline nickel based superalloy with cubic $\gamma^{\prime}$ - precipitates $\left(\mathrm{Ni}_{3} \mathrm{Al}\right)$ in the $\gamma$ - matrix. Substrate material of the test specimens with an outer diameter of $8 \mathrm{~mm}$ was nickel based superalloy IN 100, which was directionally solidified (DS) with the [100] direction of the elongated grains approximately in axial specimen direction, in order to simulate the elastic behaviour of single crystal materials as used in turbine blades. The elastic modulus in axial direction of the IN100 DS specimens was measured under tensile load with an extensometer and displays a distribution with values between 117 and $138 \mathrm{GPa}$ at room temperature and between 72 and $83 \mathrm{GPa}$ at $950^{\circ} \mathrm{C}$. The variation in elastic modulus is mainly attributed to the deviations in grain orientation.

The inner surface of the CMSX- ${ }^{\circledR}$ specimens was aluminized by a CVD process in order to reduce oxidation at the inner surface. The outer surface of all specimens was protected by a metallic oxidation protection coating. Here, only such coatings are discussed, which are made from NiCoCrAlY (nominal composition in wt $\%$ : 20Co, $21 \mathrm{Cr}, 12 \mathrm{Al}$, $0.15 \mathrm{Y}$, balance $\mathrm{Ni}$ ). The metallic oxidation protection coating is also called bond coat (BC) if an additional ceramic top coat, the TBC, is applied. Some of the specimens with NiCoCrAlY$\mathrm{BC}$ were additionally coated with a TBC. The top coat is a partially stabilized zirconia with 7-8 wt\% yttria (PYSZ), which was deposited by electron beam physical vapour deposition (EB-PVD). The NiCoCrAlY-BC was also applied by EB-PVD. During the TBC application, a $0.3 \mu \mathrm{m}$ thick alumina scale, the so called thermally grown oxide (TGO), formed between BC and ceramic top coat. Due to the TGO growth an Al-depleted zone of about $0.5 \mu \mathrm{m}$ formed in the adjacent BC.

The CMSX $-4^{\circledR}$ substrate and the aluminide coatings were produced by commercial suppliers, while the IN 100 DS material and the EB-PVD coatings were processed at DLR.

\subsection{Experimental plan}

In single crystalline gas turbine materials oriented deformation and coagulation ('rafting') of $\gamma$ '- precipitates was observed, depending on the location in the blade and thus on temperature and stress state [3]. The influence of the stress state on the rafting behaviour was the topic of the investigations on CMSX $-4^{\circledR}$. Following the rafting prediction criterion by Arell and Vallès [4], a rafting prediction chart was sketched for CMSX- $4^{\circledR}$, and stress states were identified, which result in different detectable rafting orientations and which are possible to generate with the TGMF test facility. The respective stress states were adjusted in further thermal mechanical testing by variation of mechanical load level and temperatures at the inner and outer surface of the specimens. The correlation between load and temperature difference on one hand and stress state on the other hand was taken from 3-dimensional numerical simulations.

The deformation behaviour of the metallic oxidation protection coating ('rumpling') in dependence on the multiaxial stress state was investigated systematically on the IN 100 DS system with NiCoCrAlY in fatigue experiments with (i) thermal gradient and superposed mechanical load (TGMF), (ii) thermal gradient without superposed mechanical load (TGF), and (iii) thermal cycling without thermal gradient and mechanical load (TF).

Experiments on specimens with the entire TBC system were performed in order to investigate the influence of a thermal gradient and superposed mechanical loading on the damage behaviour of the material system in comparison to thermal mechanical fatigue with homogenous temperature distribution (TMF), low cycle fatigue (LCF) with homogenous and constant temperature, and thermal fatigue, which is more commonly used for ranking of TBCs with respect to their lifetime behaviour.

In TBC systems, time dependent processes such as the TGO growth, are important for in service failure. Since it is not practical to perform test with long term cycles with the TGMF facility, part of the fatigue specimens have been pre-oxidized for several 100 hours in a separate furnace, in order to capture effects from time dependent processes. Microstructural evolution and damage features were investigated after TGMF tests with different mechanical load levels, different number of cycles, and different pre-oxidation times.

\subsection{Microscopic investigations}

The material systems were investigated by means of microscopic methods in the as processed condition and after testing, using surfaces and metallographic preparations. Cross and length sections of the CMSX $-4^{\circledR}$ substrate material were prepared along the $\{100\}$ planes of the single crystal, which makes it easier to identify the orientation of deformed and coagulated $\gamma^{\prime}$ - precipitates. Ceramic coatings were fixed with resin before preparing metallographic sections, in order to preserve the damage features in the brittle material and avoid further damage due to preparation. Scanning electron microscopy (SEM) was performed using a LEO Gemini DSM 982 SEM equipped with a field emission gun. For element analyses the energy dispersive X-ray analysis device (EDX) of the SEM (Oxford Instruments, High Wycombe, United Kingdom) was used. In the case of spallation of parts of the ceramic top coat, the metallic surface and the detached side of the top coat were examined as well. Areas of adherent ceramic top coat were fixed with resin, and length and cross sections were prepared from the specimens for further SEMinvestigations.

\section{Numerical simulation}

Linear elastic stress analyses were performed by means of Finite Element (FE) calculations in order to assess the stress distribution over the cross section of a coated specimen during the course of one TGMF cycle. The FE-code ANSYS was used for the coupled thermal and mechanical analysis. For the FE-analysis of CMSX- $4^{\circledR}$ specimens a full 3-dimensional model was generated. Because of symmetry conditions only a $45^{\circ}$-sector from the cylindrical middle section of the specimen was modelled. IN 100 DS specimens were analyzed by means of a 2-dimensional, axis symmetric FE-model of the cylindrical middle section of the coated specimen. The substrate material was modelled with orthotropic elastic prop- 
Table 1. Overview of material parameters used in finite-element simulations

Tabelle 1. Materialeigenschaften, die der FE-Simulation zu Grunde gelegt wurden.

\begin{tabular}{|c|c|c|c|c|c|}
\hline & $\begin{array}{l}\text { Substrate } \\
\text { IN } 100 \\
\text { RT } \rightarrow 1000^{\circ} \mathrm{C}\end{array}$ & $\begin{array}{l}\text { Substrate } \\
\text { CMSX-4 } \\
\text { RT } \rightarrow 1100^{\circ} \mathrm{C}\end{array}$ & $\begin{array}{l}\text { Bond coat } \\
\mathrm{NiCoCrAlY} \\
\mathrm{RT} \rightarrow 1000^{\circ} \mathrm{C}\end{array}$ & $\begin{array}{l}\mathrm{TGO} \\
\mathrm{Al}_{2} \mathrm{O}_{3} \\
\mathrm{RT} \rightarrow 1000^{\circ} \mathrm{C}\end{array}$ & $\begin{array}{l}\text { TBC } \\
\text { PYSZ } \\
\text { RT } \rightarrow 1000^{\circ} \mathrm{C}\end{array}$ \\
\hline CTE $\left[10^{-6} 1 / \mathrm{K}\right]$ & $11.5 \rightarrow 18.8$ & $12.2 \rightarrow 16.2$ & $8.6 \rightarrow 16.6$ & $6.0 \rightarrow 8.7$ & $9.0 \rightarrow 11.5$ \\
\hline$\lambda[\mathrm{W} / \mathrm{mK}]$ & $15 \rightarrow 30$ & $8.5 \rightarrow 31.2$ & $8.7 \rightarrow 27.5$ & $23 \rightarrow 5$ & $1.88 \rightarrow 1.60$ \\
\hline$\rho\left[\mathrm{g} / \mathrm{cm}^{3}\right]$ & $7.75 \rightarrow 7.29$ & 8.7 & $7.80 \rightarrow 7.43$ & 4 & $5.00 \rightarrow 4.84$ \\
\hline $\mathrm{cp}[\mathrm{J} / \mathrm{kg} \mathrm{K}]$ & $400 \rightarrow 580$ & $400 \rightarrow 960$ & $390 \rightarrow 700$ & $769 \rightarrow 1261$ & $500 \rightarrow 630$ \\
\hline $\mathrm{E}_{\text {isotropic }}[\mathrm{GPa}]$ & $215 \rightarrow 148$ & - & $140 \rightarrow 70$ & $360 \rightarrow 340$ & $13 \rightarrow 16$ \\
\hline $\mathrm{E}_{(100)}[\mathrm{GPa}]$ & $120 \rightarrow 80$ & $122 \rightarrow 94$ & - & - & - \\
\hline $\mathrm{N}^{(100)}$ & 0.3 & $0.36 \rightarrow 0.39$ & $0.322 \rightarrow 0.351$ & 0.24 & $0.22 \rightarrow 0.28$ \\
\hline
\end{tabular}
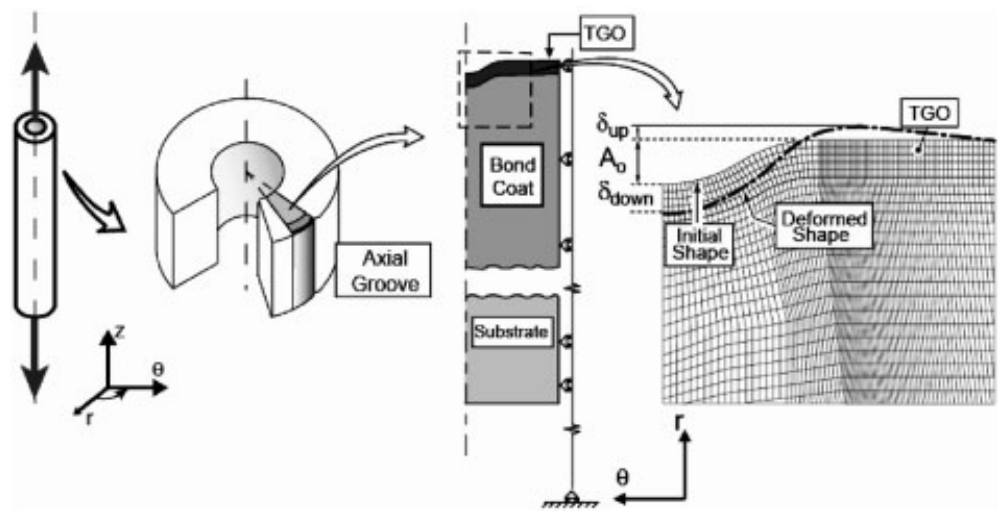

Figure 4. Finite Element model for simulating the evolution of an axial groove during thermal mechanical fatigue

Bild 4. Finite-Element-Modell für die Simulation der Entwicklung einer axial ausgerichteten Kerbe während der thermomechanischen Ermüdung erties representing the directionally solidified material consisting of a few, usually 5 to 10 , aligned crystals with the [100] direction approximately parallel to the length axis of the specimen. Perpendicular to the length axis the properties of polycrystalline IN 100 were used. The bond coat, the ceramic topcoat, and a thin TGO of $2 \mu \mathrm{m}$ were modelled for both specimen types with material data of bulk materials or, if available, of coatings, using different sources. The parameters used in the linear elastic FE-calculation are listed in table 1.

The specimen is assumed to be stress free under processing conditions, i.e. at a homogenous temperature of $1000^{\circ} \mathrm{C}$. Stationary temperature distributions were calculated for the high temperature sequence of the TGMF cycle at maximal mechanical load. The temperatures at the heated outer and cooled inner surface were taken as boundary conditions and assumed to be in the case of the CMSX- $4^{\circledR}$ specimens without TBC $1050^{\circ} \mathrm{C}$ and $980^{\circ} \mathrm{C}$, and in the case of IN 100 DS specimens with $\mathrm{TBC}$ to be $1000^{\circ} \mathrm{C}$ and $800^{\circ} \mathrm{C}$, respectively. The assumed temperature differences correspond to measurements during the high temperature sequence of the TGMF cycle.

The rumpling behaviour of the NiCoCrAlY on IN 100 DS specimens was simulated by means of the FE-code ABAQUS. A wedge-model was generated, which included a small sector of the middle part of the cylindrical specimen with the half of an initial axial groove, representing the preliminary morphological instability at the beginning of the rumpling process, see figure 4. Non linear material properties for the $\mathrm{BC}$ and simplified isotropic elastic properties for the substrate were used. The TGO was modelled as growing from an initial thickness of $1 \mu \mathrm{m}$. Growth in the TGO was imposed as stress-free strain through the user subroutine UEXPAN [5] assuming thickening and lengthening strains. A parameter study was performed investigating the influence of the high temperature
BC- 'yield' strength and of the TGO-lengthening growth strain rate on the evolution of the morphological instability in TGF and TGMF. Due to the long calculation time maximal $24 \mathrm{cy}-$ cles were simulated.

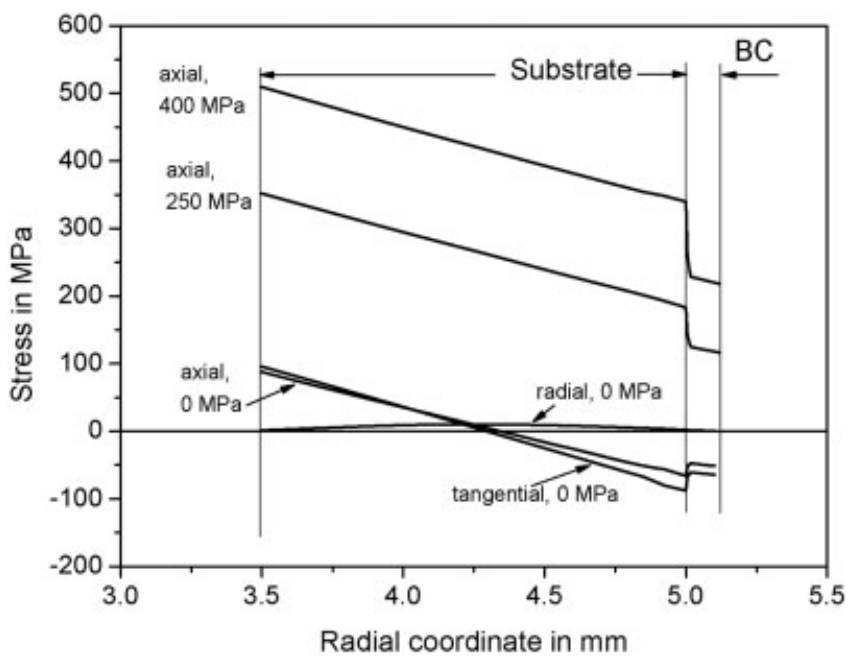

Figure 5. Stress distribution of the axial, radial, and tangential stresses over the wall of a CMSX-4 ${ }^{\circledR}$-specimen with an outer diameter of $10 \mathrm{~mm}$. The temperature difference between inner and outer wall is about $70^{\circ} \mathrm{C}$. The axial stress is shown for different maximum mechanical loads.

Bild 5. Spannungsverteilung der axialen, radialen und tangentialen Spannung über der Wand einer CMSX- $4{ }^{\circledR}$-Probe mit einem Außendurchmesser von $10 \mathrm{~mm}$. Die Temperaturdifferenz zwischen Innenund Außenwand beträgt ca. $70^{\circ} \mathrm{C}$. Die axiale Spannung ist für verschiedene maximale mechanische Lasten gezeigt. 


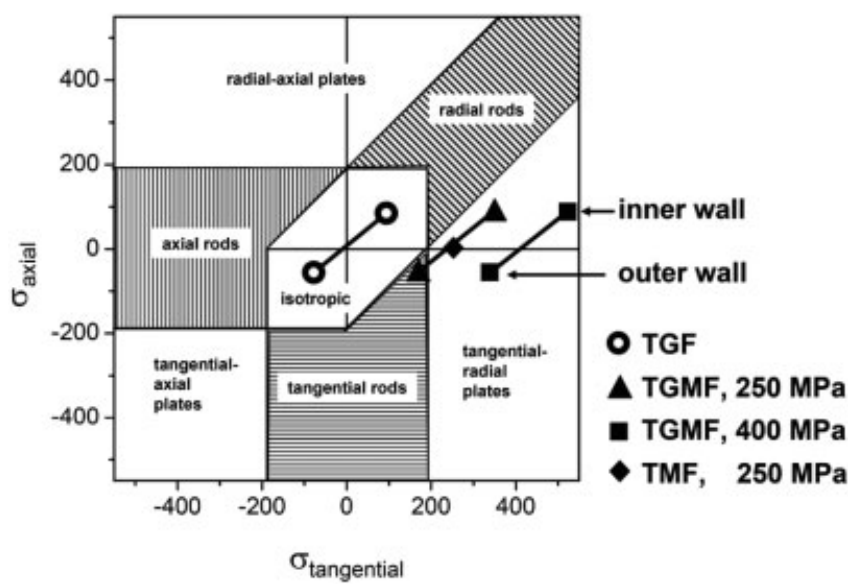

Figure 6. Rafting orientation prediction chart with indicated stress states for locations at the inner and outer wall of CMSX $-4{ }^{\circledR}$ specimens during the maximum mechanical and thermal load in the course of a thermal mechanical load cycle.

Bild 6. Vorhersagekarte für die Orientierung der Floßbildung in CMSX- $4^{\circledR}$ mit eingezeichnetem Spannungszustand für die Innenund Außenwand in den TGMF-Proben bei der maximalen Temperatur und der maximalen mechanischen Last im Verlauf eines thermomechanischen Lastzyklus

\section{Results and discussion}

\subsection{Rafting of substrate}

In TGMF and TMF experiments on CMSX $-4{ }^{\circledR}$ substrate, oriented deformation and coagulation, the so called rafting, of $\gamma^{\prime}$-precipitated has been generated. Experimental results and prediction from simulation concerning the orientation of the rafts matched very well, as described in detail in [6]. The method, how the orientation of the rafts is predicted, is illustrated in figures 5 and 6.

First the local stress states over the wall of the specimen were calculated as a function of temperature difference between inner and outer wall and superposed mechanical load, see figure 5. Since stresses in the radial direction were very small, the stress values in the tangential and axial direction for given test parameters at the inner and the outer wall of the specimen were transferred into the rafting prediction chart for biaxial stress after Arell and Vallés [4], figure 6.

From figure 6 follows that in a TGMF specimen, tested with a mechanical stress of $250 \mathrm{MPa}$, tangential-radial plates should develop at the inner wall and tangential rods near the outer wall.

In contrast, tangential-radial plates should develop over the whole wall thickness if the TGMF specimen is tested with a higher nominal mechanical stress of $400 \mathrm{MPa}$. In the cross and length sections of the tested specimens, the orientation of the rafts was deduced from the projections of the rafts. The microscopic findings did agree very well with the predictions from the simulations. Exemplarily, micrographs of the length and cross sections at the inner and outer wall of the TGMF specimen tested with a mechanical stress of $250 \mathrm{MPa}$ are shown in figure 7.

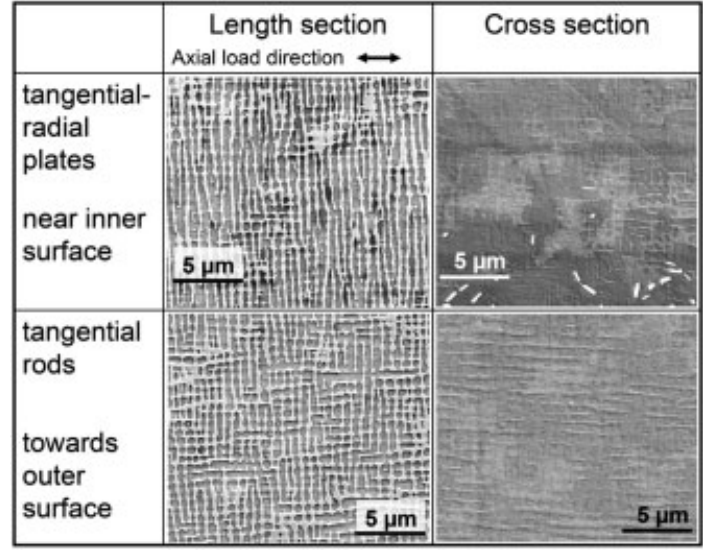

Figure 7. Micrographs of the length and cross sections of locations at the inner and outer wall of a tubular CMSX $-4^{\circledR}$ specimen tested in TGMF with a maximum mechanically induced nominal stress of $250 \mathrm{MPa}$. Cross sections are ion etched and length sections chemically etched. 'Tangential' or 'tangential radial' describes the direction of precipitate-coagulation.

Bild 7. Mikroskopische Aufnahmen von Längs- und Querschliffen nahe der inneren und äußeren Wand einer rohrförmigen CMSX-4 ${ }^{\circledR}$ Probe nach TGMF-Versuchen mit einer maximalen mechanisch induzierten nominellen Spannung von $250 \mathrm{MPa}$. Die Querschliffe sind mit Ionenstrahl und die Längsschliffe sind chemisch geätzt. 'Tangential' und 'tangential-radial' bezeichnet die Richtung der Floßbildung bzw. Koagulation der $\gamma^{\prime}$-Ausscheidungen.

\subsection{Rumpling of metallic oxidation protection layers}

TGMF-testing of bond-coated IN $100 \mathrm{DS}$ at temperatures of about $990^{\circ} \mathrm{C}$ led to intensive rumpling of the NiCoCrAlYcoating after 500 cycles. The 'rumples' were orientated parallel to the mechanical tensile load. The same number of TGFcycles generated 'rumples' without orientation. The surfaces after 500 TGMF cycles and 500 TGF cycles, respectively, are displayed in figure 8. The amplitude of the aligned 'rumples' after TGMF was higher than the amplitude of the not oriented 'rumples' in the TGF. Conducting 500 TF cycles with homogenous temperatures over the cross-section of the specimen generated no rumpling.

The simulation of the rumpling behaviour captured the accumulation of inelastic strain as well as the experimentally observed difference in amplitude of the 'rumples' or morphological instabilities after TGMF and TGF, respectively. Detailed results on numerical evaluation of different test parameters and variations in the geometrical modelling are given in [7]. Generally, compressive stress components facilitate the rumpling perpendicular to the compressive stress, while tensile stress components reduce the rumpling perpendicular to the tensile stress and accelerate it parallel to the tensile stress, resulting in aligned rumples. The parameter studies on material properties showed clearly the influence of high temperature inelastic properties of the $\mathrm{BC}$, here represented by the high temperature yield strength. As shown in figure 9, the accumulation of inelastic strain increases with decreasing high temperature 'yield strength'. Figure 10 displays the influence of the growth strain rate of the TGO on the amplitude evolution of the initial groove, corresponding to the accumulation of inelastic strain at the BC surface. An important result, elucidating the mechanism behind the rumpling phenomenon, is 


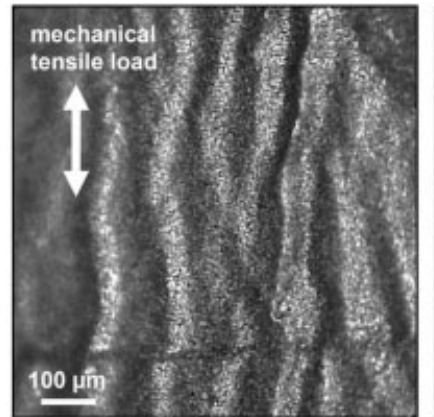

(a)

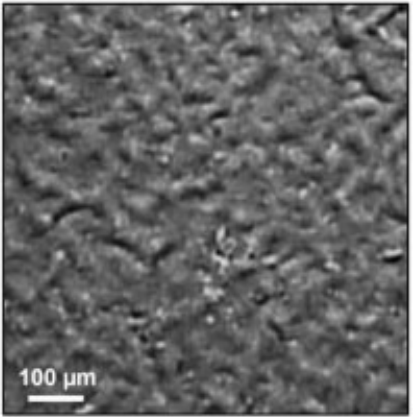

(b)

Figure 8. Surfaces of the metallic oxidation protection layer after 500 thermal cycles with a maximum stationary cycle temperature of $990{ }^{\circ} \mathrm{C}$ and a temperature difference over the specimen wall of about $200^{\circ} \mathrm{C}$, a) with a superposed mechanical load, which induced a nominal mechanical stress of $100 \mathrm{MPa}$ and $\mathrm{b}$ ) without mechanical load.

Bild 8. Oberfläche der metallischen Oxidationsschutzschicht nach 500 thermomechanischen Zyklen mit einer maximalen stationären Zyklustemperatur von $990^{\circ} \mathrm{C}$ und einer Temperaturdifferenz über der Probenwand von $200^{\circ} \mathrm{C}$, a) mit einer überlagerten mechanischen Last, die eine nominelle Spannung von $100 \mathrm{MPa}$ im Probenquerschnitt erzeugt und b) ohne überlagerte mechanische Last.

that the growth strain of the TGO is essential for the inelastic deformation to accumulate.

\subsection{Fatigue cracks in the TBC system}

TGMF tested specimens with the entire TBC system on IN 100 DS substrates displayed spallation of the ceramic top after about 1000 cycles at a nominal mechanical stress of $100 \mathrm{MPa}$ if they were pre-oxidized. The overall time at high temperature leading to spallation was about 290 to 550 hours at $1000^{\circ} \mathrm{C}$, which is significantly shorter than in TF testing where spallation was observed in the same material system after about 800 hours (and more) at $1100^{\circ} \mathrm{C}$. TGMF testing without pre-oxidation did not generate spallation of the top coat. Even a specimen, which was tested for 155 hours (in subsequent TF, TMF, TGF, and TGMF-experiments, includ-

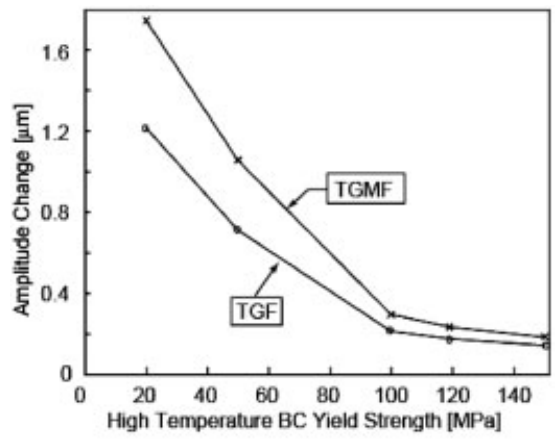

Figure 9. Amplitude change of an initial morphological instability (axial groove) after 24 thermal and thermal-mechanical cycles, respectively, as a function of the bond coat yield strength at high temperature

Bild 9. Amplitudenänderung einer anfänglichen morphologischen Instabilität (axiale Kerbe) nach 24 thermischen bzw. thermomechanischen Zyklen, als Funktion der Fließgrenze des Bondcoats bei Hochtemperatur.

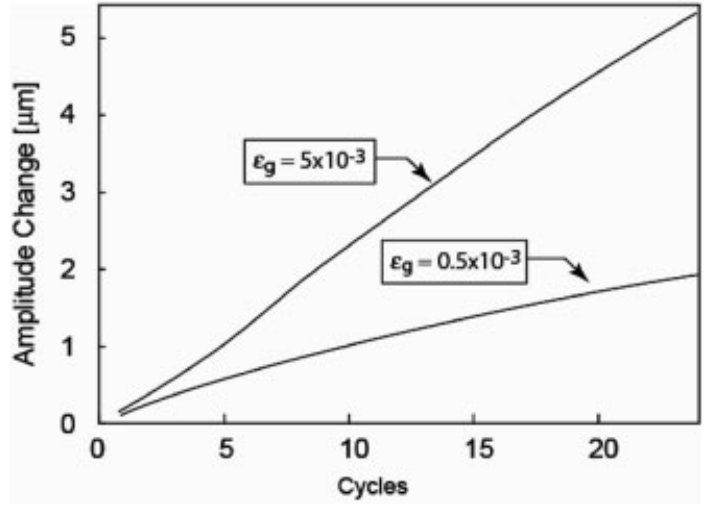

Figure 10. Amplitude change of an initial morphological instability (axial groove) with increasing number of TGMF-cycles with the growth strain rate of the TGO as parameter.

Bild 10. Amplitudenänderung einer anfänglichen morphologischen Instabilität (axiale Kerbe) mit zunehmender Zahl von TGMF-Zyklen für zwei unterschiedliche Wachstumsraten der TGO.

ing 2182 TGMF cycles with a maximal nominal tensile stress of $280 \mathrm{MPa}$ ), did not show top coat spallation.

Spallation of the top coat during or after TGMF occurred only in conjunction with specific defects. These defects evolved parallel to the surface underneath the TBC within the Al-depleted zone of the $\mathrm{BC}$ from shallow pits to the feature of the so called 'smiley' cracks. Figure 11 shows a shallow pit after 500 TGMF-cycles and figure 12 shows the classical 'smiley' - crack after 994 TGMF cycles. Pits and 'smiley' cracks, respectively, were accompanied by a narrow crack in the adjacent TGO perpendicular to the surface and to the tensile loading axis. With respect to their orientation the TGO cracks must have been generated by tensile stresses

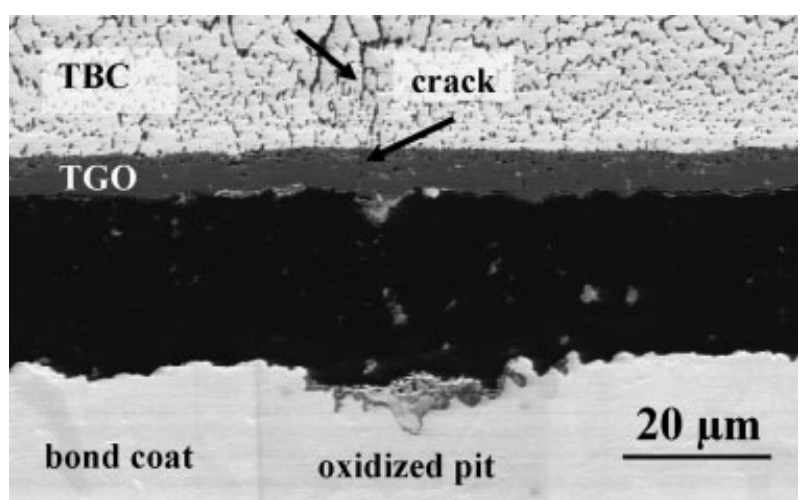

Figure 11. Length section of the initial stage of a fatigue crack (oxidized pit) evolving in the bond coat near to the interface between bond coat and TGO after 500 cycles with a maximal nominal mechanical stress of $100 \mathrm{MPa}$. The oxidized pit is associated to a crack in TGO and TBC, marked with arrows. Between TGO and bond coat is a gap, which was filled with resin before cross sectioning.

Bild 11. Längsschliff des frühen Stadiums eines Ermüdungsrisses (oxidierte Kuhle), der im Bondcoat nahe der Grenzfläche zwischen Bondcoat und TGO nach 500 Zyklen mit einer maximalen nominellen mechanischen Spannung von $100 \mathrm{MPa}$ entstanden ist. Die oxidierte Kuhle gehört zu einem Riss, der durch TGO und keramische Wärmedämmschicht geht und der mit Pfeilen markiert ist. Zwischen TGO und Bondcoat befindet sich ein Spalt, der vor der Präparation des Längsschliffs mit Kunstharz gefüllt wurde. 


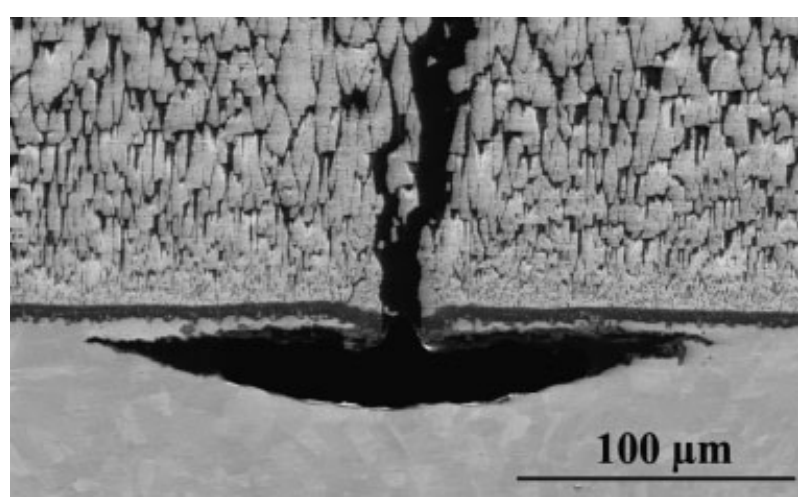

Figure 12. Length section of a fully evolved fatigue crack in the bond coat near to the interface between bond coat and TGO, showing the so called 'smiley' feature, after 994 cycles with a maximal nominal mechanical stress of $100 \mathrm{MPa}$. Note the different length scale in figure 11 and 12 .

Bild 12. Längsschliff eines voll entwickelten Ermüdungsrisses im Bondcoat nahe der Grenzfläche zwischen Bondcoat und TGO nach 994 Zyklen mit einer maximalen nominellen mechanischen Spannung von $100 \mathrm{MPa}$. Beachte den unterschiedlichen Maßstab in Bild 11 und 12

in the axial direction. Once the TGO is cracked, oxygen can access the metallic BC and weaken the material by local oxidation and an oxidation assisted fatigue crack is likely to grow. A more detailed description of the observed microstructural evolution is given in [8]. However, the linear elastic FE-calculation gives during the course of an entire TGMF cycle only compressive stresses in the TGO of at least $173 \mathrm{MPa}$ at the maximum mechanical load. Thus, the initiation of the 'smiley' cracks cannot be explained by linear elastic calculations only.

Considering inelastic deformation of the substrate, accumulation of inelastic strain in the substrate could explain further accumulation of tensile stresses in the TGO. Evidence for inelastic deformation in the substrate was found in coagulation and rafting of $\gamma^{\prime}$-precipitates in the hot centre of the IN 100 DS substrate after TGMF testing with $100 \mathrm{MPa}$ maximal nominal load [8]. However, the as-coated specimens have been loaded with even higher tensile mechanical loads and thus, higher inelastic substrate deformation should build up, entailing higher tensile stresses in the TGO.

If the possibility of inelastic deformation of the TGO is considered, as in the simulation of the rumpling phenomenon, changes in the TGO properties due to the pre-oxidation may explain the different cracking behaviour of as-coated and pre-oxidized specimens. As described by several authors $[9,10]$ and observed here as well, the TGO in the as-coated condition has an intermixed (mainly $\mathrm{Al}_{2} \mathrm{O}_{3}$ and $\mathrm{ZrO}_{2}$ ), very fine grained morphology with grain sizes of less than 100 $\mathrm{nm}$. During high temperature exposure the TGO grows and forms a dense zone (mainly $\alpha-\mathrm{Al}_{2} \mathrm{O}_{3}$ ) with grain sizes of more than $1 \mu \mathrm{m}$. Following calculations by Rösler et al. [11], the TGO can relax its stresses at high temperature due to creep processes that depend on the TGO grain size, resulting in relaxation times for the as-coated TGO at $1000^{\circ} \mathrm{C}$ of less than 1 second and for the dense TGO of more than 10 seconds. In the investigated TGMF cycle, both the 'mixed zone' and the dense TGO, should be able to relax most of the compressive stresses (induced due to the combination of thermal gradient, growth stress, and thermal property mismatch) during the first 2 minutes of the cycle.
Subsequently, an incremental mechanical load step is imposed at the end of the load cycle, which takes about 5 seconds. Therefore, there may be sufficient time for the fine-grained 'mixed zone' TGO to relax but not for the evolved 'dense zone' TGO, introducing higher tensile stress in the aged samples. This is currently being investigated and will be published at a later state [12].

The specific smiley crack feature was only observed in TGMF while LCF [13] or TMF [14, 15] did show often cracks propagating perpendicular to the mechanical load into $\mathrm{BC}$ and substrate. To the knowledge of the authors, TMF results in spallation only if high compressive mechanical loads were superposed [16].

\section{Conclusions}

The results of the performed investigations demonstrate that the microstructural evolutions in the material system reflect the influence of multiaxial stress states in thermo-mechanical fatigue. The TGMF experiments have confirmed the prediction of raft orientation in the single crystalline substrate. Since the rafting behaviour affects the macroscopic deformation of components, the good agreement between simulations and experiments motivates to utilize the rafting prediction model after Arrell and Vallés [4] in lifetime assessment procedures.

Morphological instabilities, the so called 'rumpling', as observed on surfaces of oxidation protection coatings of high pressure turbine blades after service, have been generated in TGMF and TGF experiments. The effect of the thermal gradient in these experiments has been successfully simulated. One important result of the simulation is that the growth of an oxide scale is essential to drive the increase of the amplitude of the morphological instabilities during fatigue. The rumpling phenomenon can enhance the initiation of cracks due to stress concentrations in the valleys of the morphological instabilities, which further propagate into the substrate causing fracture of the component [2]. In this context, the evolution of a TGO as function of exposure time at high temperature has to be considered in the lifetime assessment of components, which are coated by a metallic oxidation protection layer. The obtained results also imply further investigation of interaction effects between the time dependent growth of the TGO and the cycle dependent accumulation of inelastic strain, resulting in surface rumpling and eventually formation and growth of fatigue cracks.

In the case of complex coating systems with an additional TBC rumpling is suppressed as long as the ceramic adheres. If local delamination or spallation of the ceramic top coat occurs, the formation of morphological instabilities may enhance further spallation of the TBC at the free edges of the remaining top coat.

For the TBC system the composed cyclic TGMF loading has, compared to thermal cycling, a lifetime reducing effect with respect to spallation. The accelerated failure by spallation in TGMF is associated to fatigue cracks, which evolve underneath the TBC to the feature of so called 'smiley' cracks, which weaken the interface between BC and ceramic top coat. The smiley crack feature occurred only if the specimens have been pre-oxidized. Summarizing the observed defect features and the results of the FE-calculation, the 'smiley' cracks are oxidation assisted fatigue cracks, which evolve from TGO cracks that were generated perpendicular to the mechanically 
applied tensile load. The formation of the TGO cracks can only be explained by considering inelastic deformation behaviour of the TGO, which depends on exposure time at high temperature. One implication of the results for the TGMF tests is that time dependent inelastic processes in the material system may limit the acceleration of the experiment by high loading rates. Another implication is, as in the evaluation of the rumpling phenomenon, to consider the interaction between time dependent and cycle dependent processes in lifetime modelling.

\section{Acknowledgement}

The authors thank K. Mull and C. Sick for the design and implementation of the TGMF-testing facility and for the support in performing the experiments, K. Kröder, J. Brien and $\mathrm{H}$. Mangers for processing of EB-PVD coatings and substrate materials, and P. Agoston and J. Shi for their contributions in microscopic analyses and finite element calculations. Part of the work was funded by the Deutsche Forschungsgemeinschaft (DFG) and the National Science foundation (NSF) of the United States under DMR-0346664. The authors acknowledge the financial support by both research associations.

\section{References}

1. H. Biermann, Ursachen und Auswirkungen der gerichteten Vergröberung (Floßbildung) an einkristallinen NickelbasisSuperlegierungen, Düsseldorf: VDI Verlag, 1999.

2. R.C. Pennefather, D.H. Boone, Surf. Coat. Technol. 1995, 7677, 47.

3. H. Biermann, B. von Großmann, T. Schneider, S. Mechsner, H. Feng, H. Mughrabi, Z. Metallkd, 1997, 88, 666.

4. D.J. Arrell, J.L. Vallés, Scripta Met. et Mater. 1994, 30, 149.

5. ABAQUS 6.3 User's Manual, Pawtucket, Rhode Island, 2003.

6. B. Baufeld, M. Bartsch, M. Heinzelmann, Int. J. Fatigue, 2007, doi: 10.1016/j.ifatigue.2007.01.034, online available.

7. J. Shi, A.M. Karlsson, B. Baufeld, M. Bartsch, Mat. Sci. Eng. 2006, A 434, 39 .

8. M. Bartsch, B. Baufeld, S. Dalkilic, L. Chernova, M. Heinzelmann, Int. J. Fatigue, 2007, doi: 10.1016/j.ifatigue.2007.01.037, online available.

9. U. Schulz, M. Menzebach, C. Leyens, Y.Q. Yang, Surf. Coat. Technol. 2001, 146-147, 117.

10. A.M. Karlsson, J.W. Hutchinson, A.G. Evans, Mat. Sci. Eng 2003, A351, 244.

11. J. Rösler, M. Bäker, M. Volgmann, Acta mater. 2001, 49, 3659

12. M. Hernandez, M. Bartsch, A.M. Karlsson, 2007, in progress.

13. M. Bartsch, B. Baufeld, S. Dalkilic, I. Mircea, Mater. Sci. Forum 2005, 492-493, 3.

14. B. Baufeld, E. Tzimas, H. Müllejans, S. D. Peteves, J. Bressers, W. Stamm, Mater. Sci. Eng. 2001, A 315, 231.

15. A. Peichl, T. Beck, O. Vöhringer, Surf. Coat. Technol. 2003, $162,113$.

16. P.K. Wright, Mater. Sci. Eng. 1998, A245, 191.

Corresponding author: Marion Bartsch, Institut für Werkstoff-Forschung, Deutsches Zentrum für Luft- und Raumfahrt e.V. - DLR, Linder Höhe, 51147 Köln, Fax: 02203-696480,

E-mail: marion.bartsch@dlr.de 